\title{
Rheological, Organoleptical and Quality Characteristics of Gluten-Free Rice Cakes Formulated with Sorghum and Germinated Chickpea Flours
}

\author{
Mohamed G. E. Gadallah \\ Department of Food Science, Faculty of Agriculture, Ain Shams University, Cairo, Egypt \\ Email: gadnor@yahoo.com
}

How to cite this paper: Gadallah, M.G.E. (2017) Rheological, Organoleptical and Quality Characteristics of Gluten-Free Rice Cakes Formulated with Sorghum and Germinated Chickpea Flours. Food and Nutrition Sciences, 8, 535-550.

https://doi.org/10.4236/fns.2017.85037

Received: March 26, 2017

Accepted: May 19, 2017

Published: May 22, 2017

Copyright $\odot 2017$ by author and Scientific Research Publishing Inc. This work is licensed under the Creative Commons Attribution International License (CC BY 4.0).

http://creativecommons.org/licenses/by/4.0/ (c) (i) Open Access

\begin{abstract}
Gluten-free bakery products are produced for people suffering from celiac disease due to sensitivity to gluten. So, the aim of this work was to study the effect of partial substitution of rice flour at $20 \%, 30 \%$ and $40 \%$ with sorghum and germinated chickpea flours on rheological, physical, sensory properties and staling rate of prepared gluten-free cake. Obtained results showed that germinated chickpea flour had the highest contents of crude protein $(23.62 \%)$, lipids (4.89\%) and crude fibers (5.76\%) as compared to other grain flours. Gradual increase in gelatinization temperature and decrease in maximum viscosity and setback were fond of cake batters with increasing the substituting levels of rice flour from $20 \%$ to $40 \%$ with sorghum or germinated chickpea flours in comparison to rice flour batter. No significant difference was observed in specific volume between rice cake and cake containing $20 \%$ of germinated chickpea and sorghum flours which given $2.71,2.62$ and $2.56 \mathrm{~cm}^{3} / \mathrm{g}$, respectively. Data also revealed that gluten-free cake lightness $\left(\mathrm{L}^{*}\right)$ and total intensity significantly increased with $40 \%$ of sorghum flour followed by 30 and $20 \%$ of sorghum flour. Substitution of $40 \%$ rice flour with germinated chickpea flour resulted in significant high in redness $\left(\mathrm{a}^{*}\right)$, yellowness $\left(\mathrm{b}^{*}\right)$ and chroma of gluten-free cake being 11.95, 33.72 and 35.77, respectively followed by substituted levels $30 \%$ and $20 \%$ which attributed to their natural yellow pigments compared with other investigated samples. Overall acceptability of gluten-free cakes was improved after adding $20,30 \%$ of sorghum flour and $20 \%$ of germinated chickpea flour which being $90.7,88.6$ and 87.5 , respectively compared to rice flour cake (88.4). Rice flour cake was more freshness than wheat flour cake and other treatments during storage duration. After 6 days, rice cake had significant high freshness (306.2\%) followed by gluten-free cake samples with $20 \%$ of sorghum or germinated chickpea flours which given $294.5 \%$ and $289.4 \%$, respectively. Generally, it could be concluded that the
\end{abstract}


quality and nutritional properties of gluten-free rice cakes could be improved when using $20 \%, 30 \%$ of sorghum flour and $20 \%$ of germinated chickpea flour as substitution levels of rice flour.

\section{Keywords}

Coeliac Disease, Gluten-Free Cake, Sorghum Flour, Germination Chickpea Flour

\section{Introduction}

The most common disease caused by cereal protein ingestion is celiac disease. The main agents responsible for celiac disease are gluten proteins from wheat and similar proteins in other related cereals such as barley, rye and oat. The only life-long treatment is strict gluten-free food which is difficult, since many foods contain gluten [1]. Celiac disease is characterized by a strong immune response to certain amino acid sequences found in the prolamin fractions of wheat, barley and rye. When people with celiac disease eat foods containing gluten, their immune system responds by destroying the intestinal villi leading to the malabsorption of nutrients, thus adversely affecting all systems of the body [2].

Gluten-free bakery products that are prepared with gluten-free flours often tend to have reduced quantities of fiber, proteins, iron and B vitamins compared with wheat products [3]. Therefore, a redesign of the gluten-free bakery goods is needed for obtaining products with similar nutritional composition to that of their gluten counterparts. Most of the gluten-free foods produced from starch with the addition of gum. However, the gluten-free formulations containing gums as the gluten replacements lack in fibers and nutrients [4]. Rice flour has been utilized to prepare gluten-free bakery products, such as bread and cake, which are traditionally made with wheat flour. Rice is naturally gluten-free and contains proteins that are known to be nutritious and hypoallergenic [5]. Sorghum (Sorghum bicolor) is a gluten-free grain with high potential in the gluten-free food processing. It is the $5^{\text {th }}$ largest crop produced worldwide and has been shown to be safe for celiac disease people [6].

Chickpea (Cicer arietinum L.) is an annual grain legume that is cultivated in the Mediterranean basin, the Near East, Central and South Asia, East Africa, South and North America, and Australia for human consumption [7]. It is the second most important pulse crop in the world (after dry bean), covering 14\% (7.9 million tons) of pulse production worldwide (FAOSTAT) [8]. Chickpea seed has a high protein digestibility, good balance of amino acid, contains high levels of complex carbohydrates (low glycemic index), is rich in vitamins and minerals and is relatively low levels of anti-nutritional factors [9] [10]. Germination can be improved legume digestibility and reducing flatulence properties, which are some of the factors that restrict consumption. Germinated legumes are a good source of highly bioavailable proteins, starch, lipids and minerals. 
Additionally, germinated seeds contain significant amounts of polyphenols with well pro-health properties [11] [12]. Hydrocolloids (such as xanthan gum, guar gum and pectin) are added to naturally gluten-free flour to mimic the viscoelastic properties of gluten and to improve sensory properties, structure, and shelf-life of these products [13] [14].

The aim of the present study is to investigate the effect of partial substitution of rice flour by sorghum and germinated chickpea flours on pasting, physicochemical, sensory and staling properties of gluten-free rice cakes.

\section{Materials and Methods}

\subsection{Materials}

Commercial wheat flour (72\% extraction), rice flour, sorghum (Sorghum bicolor) grains, chickpea (Cicer arietinum L.) seeds, Shortening, nonfat dry milk, sugar, eggs, salt and baking powder were purchased from the local market, $\mathrm{Bu}$ raidah, Qassim, Saudi Arabia. Xanthan gum was obtained from Sigma chemical Co. (St. Louis, Mo), USA.

\subsection{Methods}

\subsubsection{Preparation of Sorghum Flour}

Sorghum grains were cleaned from foreign materials, tempered to $15 \%$ moisture content and milled using laboratory mill (3100, Perten Instruments, Sweden) to obtained whole sorghum flour. Sorghum flour was packed in polyethylene bags and stored at $\left(-18^{\circ} \mathrm{C}\right)$ until used [15].

\subsubsection{Preparation of Germinated Chickpea Flour}

Germinated chickpea flour was prepared according to the method described by Fernandez-Orozco et al., [16]. Chickpea seeds were cleaned from all impurities, washed and soaked in four volumes of tap water for $12 \mathrm{~h}$ under ambient laboratory conditions $\left(22^{\circ} \mathrm{C}-25^{\circ} \mathrm{C}\right)$. The seeds were allowed to germinate after drained the water under a wet muslin cloth in the dark at $22^{\circ} \mathrm{C}-25^{\circ} \mathrm{C}$ for $48 \mathrm{~h}$. The germinated seeds were collected and dried in an air dryer oven at $55^{\circ} \mathrm{C}$ for $16 \mathrm{~h}$. Germinated seeds were dehulled and milled to flour using a laboratory mill (3100, Perten Instruments, Sweden) and sieved through a 50 mesh screen. The resultant flour was packed in polyethylene bags and stored under frozen condition until used.

\subsubsection{Chemical Analysis}

Wheat, rice, sorghum and germinated chickpea flours were chemically analyzed for their moisture content, ash, crude protein, lipids and crud fiber contents according to the methods described in AOAC [17]. The nitrogen free extract (NFE) was calculated by difference.

\subsubsection{Determination of Tannins and Trypsin Inhibitors}

Tannins according to the method of Hagerman [18], and trypsin inhibitors according to the method of Hamerstrand et al., [19] were determined for chickpea 
seeds flour before and after germination at 3 days.

\subsubsection{Rheological Properties}

Rheological properties of the various gluten-free blends consist of rice flour with sorghum or germinated chickpea flours were determined by Barbender ViscoAmylograph according to AACC [20].

\subsubsection{Preparation of Gluten-Free Cake Samples}

Gluten-free cakes were prepared according to the method of Levent and Bilgicili [21]. The control rice cake was prepared by whipping shortening (150 g) and sugar $(150 \mathrm{~g})$ to a white cream in a Hobart mixer (Hobart N50, Canada Inc., North York, Canada). Then egg (150 g) was added and whipped for $5 \mathrm{~min}$, then the other ingredients, rice flour $(200 \mathrm{~g})$, nonfat dry milk $(10 \mathrm{~g})$, baking powder $(9 \mathrm{~g})$, salt $(1 \mathrm{~g})$ and xanthan gum $(1 \mathrm{~g})$ were added and the batter was mixed for additional $1 \mathrm{~min}$. One hundred and fifty grams of cake batter were placed into baking pans with $7.5 \times 6.5 \times 12 \mathrm{~cm}$ dimensions and baked at $180^{\circ} \mathrm{C}$ for $40 \mathrm{~min}$ in a baking oven (Bosch HBT 112, Athens, Greece). The treatments were carried out by substituted rice flour with sorghum or germinated chickpea flours at 20 , $30 \%$ and $40 \%$. Also, control wheat flour cake was prepared to compare with the treatments. After baking, gluten-free cakes were cooled for one hour to room temperature $\left(24^{\circ} \mathrm{C} \pm 2^{\circ} \mathrm{C}\right)$, then packaging in polyethylene bags and stored at room temperature for six days.

\subsubsection{Specific Gravity of Batter and Measurements of Cakes}

Specific gravity of cake batter was calculated according to the method of Jyotsna et al., [22]; weight $(\mathrm{g})$, volume $\left(\mathrm{cm}^{3}\right)$ and specific volume $\left(\mathrm{cm}^{3} / \mathrm{g}\right)$ of different cake samples were measured according to the method of Bennion and Bamford [23].

\subsubsection{Color Measurement of Gluten-Free Cakes}

Crumb color of gluten-free cakes was evaluated according to the method described by Francis [24] using a Hunter Lab Color QUEST II Minolta CR-400 (Minolta Camera, Co., Ltd., Osaka, Japan) by measuring the L $(100=$ white; $0=$ black), a (+, red; -, green) and b (+, yellow; -, blue) values.

\subsubsection{Sensory Evaluation of Gluten-Free Cakes}

Gluten-free cake samples were assessed for their quality attributes after baking by ten members preference taste panels of food science and human nutrition department staff. They were asked to score the internal characteristics of cake samples i.e. cell uniformity, grain, texture, crumb color and flavor using the respect sheet according to AACC [20].

\subsubsection{Determination of Gluten-free Cake Staling}

The staling rate of different prepared gluten-free cakes was determined after baking within one hour and after 2, 4 and 6 days of storage at room temperature $\left(24^{\circ} \mathrm{C} \pm 2^{\circ} \mathrm{C}\right.$ ) by alkaline water retention capacity (AWRC \%) according to the AACC 56-10 method AACC [20]. 


\subsubsection{Statistical Analysis}

Data were expressed as the means \pm SE. Statistical analysis was carried out using the PROC ANOVA followed by Duncan's Multiple Range Test with $\mathrm{p} \leq 0.05$ being considered statistically significant to compare between means according to Snedecor and Cochran [25]. All procedures were plicate using Statistical Analysis System program [26].

\section{Results and Discussion}

\subsection{Chemical Composition of Wheat Flour and Gluten-Free Flours}

The proximate chemical composition of gluten-free flours compared to wheat flour used in gluten-free cakes preparation was determined and the obtained data are listed in Table 1. It could be observed that wheat and sorghum flours had significant $(\mathrm{p} \leq 0.05)$ high in moisture content being $13.16 \%$ and $12.82 \%$, respectively. On the other hand, used rice flour was containing lower moisture content $8.50 \%$. Germinated chickpea flour showed significant $(\mathrm{p} \leq 0.05)$ increase in ash $(3.10 \%)$ followed by $2.58 \%$ which given by sorghum flour, while wheat and rice flours were contained lower amounts of ash being 0.52 and $0.44 \%$, respectively. Also, results in the same table revealed that the highest contents of crude protein $(23.62 \%)$, lipids (4.89\%) and crude fibers $(5.76 \%)$ were given by germinated chickpea flour when compared to other used materials. These results are in agreement with Yousif and Faid [27] who found that germination caused increased of crude protein, amino acid contents, total dietary fiber, soluble and insoluble dietary fibers. In addition, rice flour has significant $(\mathrm{p} \leq 0.05)$ high of nitrogen free extract (88.22\%) followed by wheat flour which recorded $85.75 \%$, while the lowest nitrogen free extract $(62.63 \%)$ was given by germinated chickpea flour. Similar findings are in accordance with Ranjbar et al., [28] in chemical composition of rice flour. Leaching out of solid matter during soaking in water before germination resulted in significant reduction of nitrogen free extract content of germinated legume flour [29] [30].

\subsection{Tannins and Trypsin Inhibitors of Chickpea Flour}

The antinutritional factors of raw and germinated chickpea flours were determined and the data are illustrated by Figure 1. It could be found that germina-

Table 1. Proximate composition of wheat flour and gluten-free flours (\% on dry weight basis).

\begin{tabular}{|c|c|c|c|c|c|c|}
\hline Treatments & Moisture & Ash & Crude protein ${ }^{*}$ & Lipids & Crude fiber & $\begin{array}{c}\text { Nitrogen free } \\
\text { extract }(\mathrm{NFE})^{\star *}\end{array}$ \\
\hline Wheat flour & $13.16 \pm 0.07^{\mathrm{a}}$ & $0.52 \pm 0.04^{\mathrm{c}}$ & $10.73 \pm 0.11^{b}$ & $1.85 \pm 0.06^{\mathrm{b}}$ & $1.15 \pm 0.09^{c}$ & $85.75 \pm 0.23^{\mathrm{b}}$ \\
\hline Rice flour & $8.50 \pm 0.12^{c}$ & $0.44 \pm 0.06^{\mathrm{c}}$ & $9.56 \pm 0.23^{c}$ & $1.28 \pm 0.11^{\mathrm{c}}$ & $0.50 \pm 0.08^{\mathrm{d}}$ & $88.22 \pm 0.13^{\mathrm{a}}$ \\
\hline Sorghum flour & $12.82 \pm 0.17^{\mathrm{a}}$ & $2.58 \pm 0.09^{b}$ & $8.38 \pm 0.06^{\mathrm{d}}$ & $2.25 \pm 0.14^{\mathrm{b}}$ & $3.51 \pm 0.12^{b}$ & $83.28 \pm 0.11^{\mathrm{c}}$ \\
\hline $\begin{array}{l}\text { Germinated } \\
\text { chickpea flour }\end{array}$ & $9.48 \pm 0.17^{\mathrm{b}}$ & $3.10 \pm 0.05^{\mathrm{a}}$ & $23.62 \pm 0.29^{a}$ & $4.89 \pm 0.17^{\mathrm{a}}$ & $5.76 \pm 0.21^{\mathrm{a}}$ & $62.63 \pm 0.32^{\mathrm{d}}$ \\
\hline
\end{tabular}

Data are the mean $\pm S E ; n=3$, Values followed by the same letters in the same column are not significantly different $(\mathrm{p} \leq 0.05)$. $(\mathrm{NFE})^{* *}$ : calculated by difference. ${ }^{*}$ Wheat, sorghum and rice flours $(\mathrm{N} \times 5.70)$ while, chickpea flour $(\mathrm{N} \times 6.25)$. 


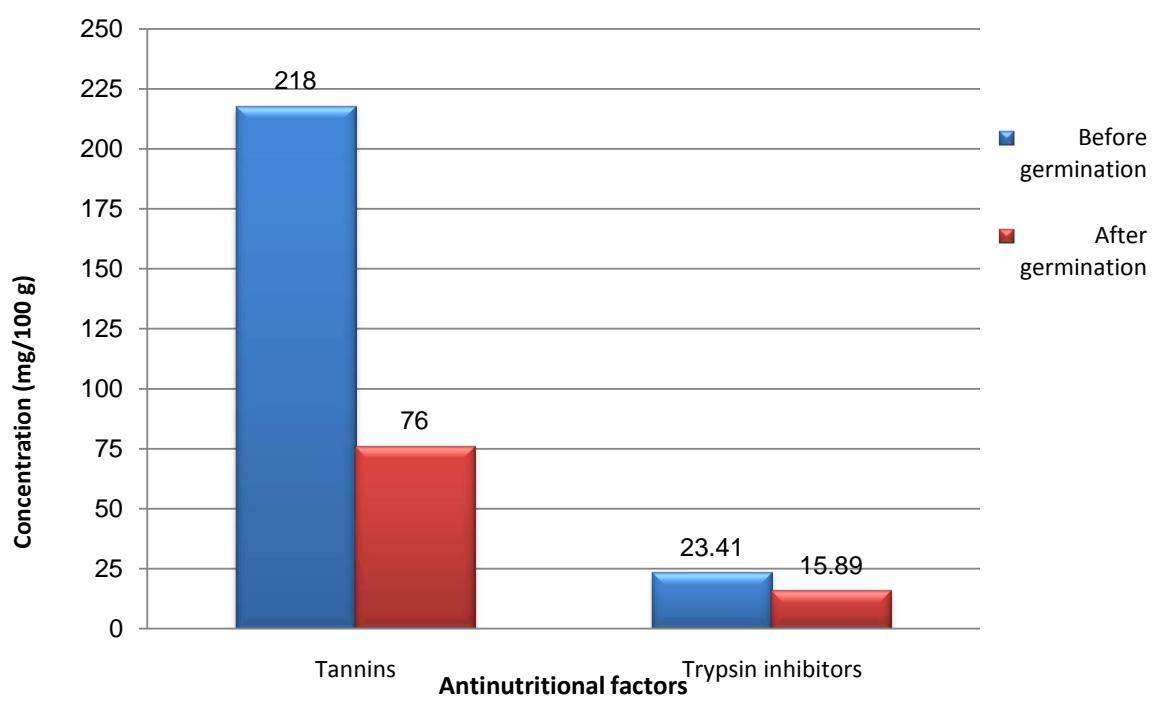

Figure 1. Tannins and trypsin inhibitors contents of raw and germinated chickpea flours.

tion has positive effect on reduction of tannins and trypsin inhibitors concentrations in germinated chickpea flour. Tannins level was decreased from $218 \mathrm{mg} /$ $100 \mathrm{~g}$ in raw chickpea flour to $76 \mathrm{mg} / 100 \mathrm{~g}$ in germinated chickpea flour. In addition, the raw chickpea flour was contained $23.41 \mathrm{mg}$ of trypsin inhibitors activity/100g which reduced by germination procedure to $15.89 \mathrm{mg} / 100 \mathrm{~g}$ in germinated chickpea flour. These results are going in parallel with those of Ghavidel and Prakash [31]; Yousif and Faid [27]. Cevallos-Casals, and Cisneros-Zevallos [11] reported that germinated legumes are a good source of highly bioavailable proteins, starch, lipids and minerals. Also, Legume digestibility was improved by germination and reducing the flatulence properties, which are the main factors that restrict of consumption.

\subsection{Visco-Amylograph Parameters of Gluten-Free Blends}

Visco-amylograph properties are functions of the various parameters of flour like shape, size, hydrophilic and hydrophobic balance of the molecules, carbohydrates associated with proteins, solubility of starch and thermodynamic properties of the system [32]. Data in Table 2 show the visco-amylogram results of rice flour and its blends with sorghum and germinated chickpea flours which used for gluten-free cake preparation. It could be found that increasing of substituting levels of rice flour with sorghum or germinated chickpea flours from 20 to $40 \%$ resulted in gradually increased in gelatinization temperature from 69.7 to $76.5^{\circ} \mathrm{C}$ in case of sorghum flour and from $73.2^{\circ} \mathrm{C}$ to $77.4^{\circ} \mathrm{C}$ in case of germinated chickpea flour. Also, the temperature at maximum viscosity was increased as a result to increasing the gelatinization temperature when compared to $91.5^{\circ} \mathrm{C}$ for rice flour. Pasting temperature provides an indication of the minimum temperature required to cook the flour [33]. The decrease in maximum viscosity of gluten-free blends was observed from 530 to 450 B.U for substituting rice flour with sorghum flour at $20 \%$ to $40 \%$, respectively and from 420 to 350 B.U when subs- 
Table 2. Visco-amylograph parameters of wheat flour and gluten-free flours blends.

\begin{tabular}{|c|c|c|c|c|c|c|}
\hline \multirow{2}{*}{ Treatments } & \multirow{2}{*}{$\begin{array}{l}\text { Gelatinization } \\
\text { temp. }{ }^{\circ} \mathrm{C}\end{array}$} & \multicolumn{2}{|c|}{$\begin{array}{l}\text { Maximum } \\
\text { Viscosity }\end{array}$} & \multirow{2}{*}{$\begin{array}{l}\text { Viscosity at } \\
95^{\circ} \mathrm{C} \text { (B.U) }\end{array}$} & \multirow{2}{*}{$\begin{array}{l}\text { Viscosity at } \\
50^{\circ} \mathrm{C}(\mathrm{B} . \mathrm{U})\end{array}$} & \multirow{2}{*}{$\begin{array}{c}\text { Setback } \\
\text { (B.U) }\end{array}$} \\
\hline & & ${ }^{\circ} \mathrm{C}$ & B. $U^{*}$ & & & \\
\hline Wheat flour & 61.8 & 88.7 & 525 & 412 & 608 & 196 \\
\hline Rice flour (RF) & 66.3 & 91.5 & 580 & 520 & 980 & 460 \\
\hline RF $80 \%$ with SF $20 \%$ & 69.7 & 93.0 & 530 & 430 & 860 & 430 \\
\hline RF 70\% with SF 30\% & 73.0 & 93.5 & 480 & 390 & 750 & 360 \\
\hline RF $60 \%$ with SF $40 \%$ & 76.5 & 95.0 & 450 & 340 & 660 & 320 \\
\hline RF $80 \%$ with GCF $20 \%$ & 73.2 & 93.0 & 420 & 390 & 790 & 400 \\
\hline RF 70\% with GCF $30 \%$ & 75.6 & 95.5 & 380 & 370 & 630 & 260 \\
\hline RF $60 \%$ with GCF $40 \%$ & 77.4 & 97.0 & 350 & 320 & 540 & 220 \\
\hline
\end{tabular}

SF: Sorghum flour; GCF: Germinated chickpea flour; ${ }^{\star}$ B.U: Brabender Unit, Setback $=$ viscosity at $50^{\circ} \mathrm{C}-$ viscosity at $95^{\circ} \mathrm{C}$.

tituting rice flour with germinated chickpea flour at $20 \%$ to $40 \%$, respectively in comparison to 580 B.U for rice flour. These results may be attributed to the low content of carbohydrates (NFE) in each of sorghum and germinated chickpea flours which recorded 83.28 and $62.63 \%$, respectively compared to rice flour 88.22 (Table 1). Incorporation of protein isolates with rice flour decreased paste peak viscosity and increased batter viscoelasticity [34].

The general trend of viscosity at $95^{\circ} \mathrm{C}$ and at $50^{\circ} \mathrm{C}$ is the reduction with increasing the replacement ratio or rice flour with sorghum and germinated chickpea flours. Whereas, viscosity at $95^{\circ} \mathrm{C}$ ranged between 430 and 320 B.U for $20 \%$ of sorghum flour and $40 \%$ of germinated chickpea flour, respectively compared to $570 \mathrm{~B} . \mathrm{U}$ for rice flour, as well as viscosity at $50^{\circ} \mathrm{C}$ ranged from 860 to 540 B.U for $20 \%$ of sorghum flour and $40 \%$ of germinated chickpea flour, respectively compared to 980 B.U for rice flour. These findings are in harmony with those obtained by Yousif and Faid [27] as they found gradually decreased in maximum viscosity with increasing the replacement levels of corn and rice flour mixture at $10 \%, 20 \%$ and $30 \%$ with dehulling sweet lupine or chickpea flours. It could be also noticed that maximum viscosity, viscosity at 95 and $50^{\circ} \mathrm{C}$ of wheat flour were lower than those for rice flour. Setback viscosity is the gelling of cooked starch that occurs as straight chain amylose molecules begin to realign and form a stable gel structure. Setback measure of retrogradation tendency of starch upon cooling of cooked starch pastes [35]. Rice flour had the highest setback value (460 B.U) and the substituting levels 20,30 and $40 \%$ of rice flour with sorghum and germinated chickpea flours caused a reduction of setback of blends. Shevkani, et al., [36] stated that with increasing levels of protein isolates in rice flour, breakdown viscosity was decreased indicated that more proteins gave the starch granules a greater stability at high temperature. Ouazib, et al., [37] reported that pasting properties of the wheat-chickpea blends were significantly modified due to wheat flour replacement by $10 \%$ and $20 \%$. 


\subsection{Cake Batters and Gluten-Free Cakes Measurements}

The amount of air incorporated into a cake batter can be evaluated by measuring the batter's specific gravity; whereas low specific gravity is indicated good aeration of batter [38] [39]. Specific gravity of cake batters are illustrated by Figure 2 and physical properties of prepared gluten-free cake are given in Table 3. Statistical analysis of results observed that addition sorghum and germinated chickpea flours with rice flour resulted in significant $(\mathrm{p} \leq 0.05)$ increase in specific gravity of batters when compared to rice flour batter. No significant $(\mathrm{p} \leq 0.05)$ difference was found between specific gravity of rice flour batter, 20 and $30 \%$ sorghum flour which recorded $0.87,0.88$ and 0.90 , respectively. On the other hand, the highest specific gravity values 0.99 and 0.95 were given by incorporated $40 \%$ of germinated chickpea flour and $40 \%$ of sorghum flour, respectively.

Concerning to gluten-free cake properties in Table 3, No significant $(\mathrm{p} \leq 0.05)$

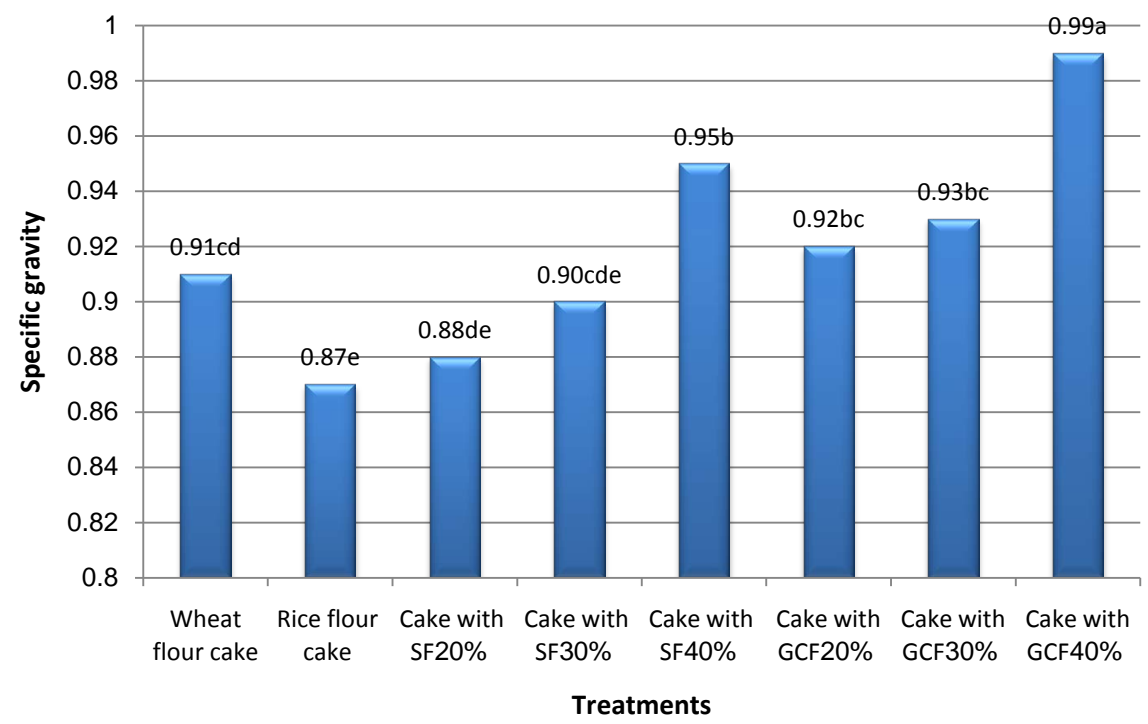

Figure 2. Specific gravity of gluten-free batters with sorghum and germinated chickpea flours.

Table 3. Physical measurements of prepared gluten-free rice cakes.

\begin{tabular}{lccc}
\hline Treatments & Cake weight $(\mathrm{g})$ & Cake volume $\left(\mathrm{cm}^{3}\right)$ & Specific volume $\left(\mathrm{cm}^{3} / \mathrm{g}\right)$ \\
\hline Wheat flour cake & $133.8 \pm 0.81^{\mathrm{ab}}$ & $375 \pm 3.48^{\mathrm{a}}$ & $2.80 \pm 0.02^{\mathrm{a}}$ \\
Rice flour cake & $128.5 \pm 0.86^{\mathrm{b}}$ & $348 \pm 7.32^{\mathrm{bc}}$ & $2.71 \pm 0.11^{\mathrm{ab}}$ \\
Cake with 20\% SF & $135.3 \pm 0.77^{\mathrm{ab}}$ & $345 \pm 2.88^{\mathrm{bc}}$ & $2.56 \pm 0.13^{\mathrm{bc}}$ \\
Cake with 30\% SF & $137.6 \pm 0.46^{\mathrm{a}}$ & $337 \pm 1.73^{\mathrm{bc}}$ & $2.44 \pm 0.01^{\mathrm{c}}$ \\
Cake with 40\% SF & $138.6 \pm 0.58^{\mathrm{a}}$ & $290 \pm 5.77^{\mathrm{d}}$ & $2.09 \pm 0.03^{\mathrm{d}}$ \\
Cake with 20\% GCF & $135.4 \pm 1.31^{\mathrm{ab}}$ & $355 \pm 2.88^{\mathrm{ab}}$ & $2.62 \pm 0.02^{\mathrm{abc}}$ \\
Cake with 30\% GCF & $138.1 \pm 3.53^{\mathrm{ab}}$ & $327 \pm 7.50^{\mathrm{c}}$ & $2.37 \pm 0.03^{\mathrm{bc}}$ \\
Cake with 40\% GCF & $141.2 \pm 0.58^{\mathrm{a}}$ & $275 \pm 8.66^{\mathrm{d}}$ & $1.95 \pm 0.07^{\mathrm{d}}$ \\
\hline
\end{tabular}

SF: Sorghum flour; GCF: Germinated chickpea flour; Data are the mean \pm SE, $n=3$, Mean values in the same column bearing the same superscript do not differ significantly $(\mathrm{p} \leq 0.05)$. 
difference was appeared in cake weights between all of treatments except cake prepared from only rice flour which recorded the lowest value (128.5 g). Gradually increase was found in cake weight from 135.3 to $138.6 \mathrm{~g}$ and from 135.4 to $141.2 \mathrm{~g}$ when increasing levels from $20 \%$ to $40 \%$ of sorghum flour and from $20 \%$ to $40 \%$ of germinated chickpea flour, respectively. These results may be due to the high crude fiber content in sorghum and germinated chickpea flours which characterized by high water holding capacity (Table 1).

As expected, wheat flour cake had the highest volume $375 \mathrm{~cm}^{3}$ followed by gluten-free cake with $20 \%$ germinated chickpea flour which given $355 \mathrm{~cm}^{3}$ and without significant difference. Contrarily, using $40 \%$ of sorghum flour or germinated chickpea flour lead to significant ( $\mathrm{p} \leq 0.05)$ decrease in cake volume being 290 and $275 \mathrm{~cm}^{3}$, respectively as compared to rice flour cake $348 \mathrm{~cm}^{3}$. These results are in agreement with Gomez et al., [40] and Herranz, et al., [12] as they reported that supplemented of cakes with chickpea flour resulted in lower gas retention and lower expansion of cake and the volume was decreased with increasing levels of chickpea flour.

Specific volume of cakes is depending on cake volume so; a similar trend was observed. It could be easily to say that, no significant $(\mathrm{p} \leq 0.05)$ difference was observed in specific volume between wheat cake, rice cake and cake containing $20 \%$ germinated chickpea flour which given $2.80,2.71$ and $2.62 \mathrm{~cm}^{3} / \mathrm{g}$, respectively. Moreover, with increasing of sorghum or germinated chickpea flours levels in gluten-free cake, the specific volume was slightly decreased. Levent and Bilgicli [21] reported that cakes volume index improved with buckwheat flour at $5 \%$ or lupine flour up to $20 \%$ levels compared to control. Ouazib, et al., [37] stated that germinated chickpea flour was the most appropriate flour for wheat replacement up to $20 \%$ pertaining bread specific volume, crumb hardness and nutritional composition (higher protein content).

\subsection{Color Attributes of Gluten-Free Cakes}

Color is one of the most important sensory attribute that affect directly the consumer preference of any product. Crumb color of gluten-free cakes prepared from rice flour with $20 \%, 30 \%$ and $40 \%$ of sorghum or germinated chickpea flour was determined and obtained results are tabulated in Table 4. Gluten-free cake containing $40 \%$ sorghum flour had significant $(\mathrm{p} \leq 0.05$ ) high in lightness $\left(L^{*}\right)$ being 73.88 followed by 68.57 and 65.45 which given by incorporated 30 and $20 \%$ of sorghum flour in gluten-free cake. On the other hand, germinated chickpea flour at $40 \%$ in cake caused significant $(\mathrm{p} \leq 0.05)$ low in lightness (darker) being 56.87 followed by 59.60 which recorded by $30 \%$ of germinated chickpea flour when compared to wheat and rice cakes. Such findings are in agreement with Hussein et al., [41] as they found that gluten-free cake prepared from germinated rice flour was darker than cake with sorghum, rice and wheat flours.

Millard reaction fails to take place in cake crumb because it does not reach above $100^{\circ} \mathrm{C}$, therefore crumb color reflects of used raw materials colors and 
Table 4. Crumb color parameters of prepared gluten-free rice cake samples.

\begin{tabular}{lccccc}
\hline Treatments & $\mathrm{L}^{*}$ & $\mathrm{a}^{*}$ & $\mathrm{~b}^{*}$ & $\begin{array}{c}\text { Total } \\
\text { Intensity (I) }\end{array}$ & $\begin{array}{c}\text { Chroma } \\
(\mathrm{C})\end{array}$ \\
\hline Wheat flour cake & $62.70 \pm 0.55^{\mathrm{d}}$ & $8.83 \pm 0.08^{\mathrm{c}}$ & $21.57 \pm 0.43^{\mathrm{g}}$ & $63.31 \pm 0.56^{\mathrm{d}}$ & $23.31 \pm 0.38^{\mathrm{f}}$ \\
Rice flour cake & $64.04 \pm 0.14^{\mathrm{c}}$ & $5.13 \pm 0.07^{\mathrm{e}}$ & $19.47 \pm 0.11^{\mathrm{h}}$ & $65.24 \pm 0.13^{\mathrm{c}}$ & $20.14 \pm 0.12^{\mathrm{g}}$ \\
Cake with 20\% SF & $65.45 \pm 0.25^{\mathrm{c}}$ & $4.55 \pm 0.02^{\mathrm{f}}$ & $24.34 \pm 0.47^{\mathrm{f}}$ & $65.62 \pm 0.25^{\mathrm{c}}$ & $24.77 \pm 0.48^{\mathrm{e}}$ \\
Cake with 30\% SF & $68.57 \pm 0.07^{\mathrm{b}}$ & $3.86 \pm 0.34^{\mathrm{g}}$ & $27.23 \pm 0.09^{\mathrm{e}}$ & $68.67 \pm 0.08^{\mathrm{b}}$ & $27.53 \pm 0.14^{\mathrm{d}}$ \\
Cake with 40\% SF & $73.88 \pm 0.38^{\mathrm{a}}$ & $3.15 \pm 0.09^{\mathrm{h}}$ & $31.45 \pm 0.10^{\mathrm{b}}$ & $73.95 \pm 0.38^{\mathrm{a}}$ & $31.60 \pm 0.09^{\mathrm{b}}$ \\
Cake with 20\% GCF & $62.74 \pm 0.28^{\mathrm{d}}$ & $7.55 \pm 0.06^{\mathrm{d}}$ & $28.82 \pm 0.28^{\mathrm{d}}$ & $63.19 \pm 0.27^{\mathrm{d}}$ & $29.79 \pm 0.29^{\mathrm{c}}$ \\
Cake with 30\% GCF & $59.60 \pm 0.29^{\mathrm{e}}$ & $10.34 \pm 0.05^{\mathrm{b}}$ & $30.59 \pm 0.02^{\mathrm{c}}$ & $60.49 \pm 0.30^{\mathrm{e}}$ & $32.29 \pm 0.04^{\mathrm{b}}$ \\
Cake with 40\% GCF & $56.87 \pm 0.37^{\mathrm{f}}$ & $11.95 \pm 0.19^{\mathrm{a}}$ & $33.72 \pm 0.12^{\mathrm{a}}$ & $58.12 \pm 0.32^{\mathrm{f}}$ & $35.77 \pm 0.05^{\mathrm{a}}$
\end{tabular}

SF: Sorghum flour; GCF: Germinated chickpea flour; Data are the mean \pm SE, $n=3$, Mean values in the same column bearing the same superscript do not differ significantly $(P \leq 0.05)$. $L^{\star}$ : lightness; $a^{*}$ : redness; $b^{*}$ : yellowness.

their interactions [40]. It could be noticed that substituted rice flour at $40 \%$ with germinated chickpea flour in gluten-free cake resulted in significant $(\mathrm{p} \leq 0.05)$ increase in redness $\left(\mathrm{a}^{\star}\right)$, yellowness $\left(\mathrm{b}^{\star}\right)$ and chroma being $11.95,33.72$ and 35.77 , respectively followed by substituted levels 30 and $20 \%$ compared with other treatments, wheat and rice cake samples. These results may be due to the natural pigments in germinated chickpea flour which had a positive effect on yellowness of prepared gluten-free cakes. Shevkani et al., [34] Mentioned that white cowpea protein isolate influenced crumb color of gluten-free rice muffin $\left(L^{*}, a^{*}\right.$ and $\left.b^{*}\right)$ marginally whereas red cowpea protein isolate increased $a^{*}$ while decreased $\mathrm{L}^{\star}$ and $\mathrm{b}^{\star}$ significantly.

The same trend of lightness was found in case of cake total intensity, whereas cake sample containing $40 \%$ sorghum flour exhibited significant $(\mathrm{p} \leq 0.05)$ increase in total intensity value 73.95 followed by incorporated levels 30 and $20 \%$ which recorded 68.67 and 65.62, respectively compared to other selected treatments. Xu and Diosady, [42] reported that the differences in protein sources color might be due to the presence of different coloring constituents in the flours, like polyphenols, that might have interacted with the proteins.

\subsection{Sensory Characteristics of Gluten-Free Cakes}

The influence of substitution different levels of rice flour with sorghum or germinated chickpea flours on sensory quality of gluten-free cake was evaluation and data are found in Table 5. It was clear that wheat flour cake had the highest values with significant high in all sensory scores except crumb color in comparison with rice cake and other substituted treatments. Incorporated of sorghum flour at $20 \%$ in prepared cake caused significant $(\mathrm{p} \leq 0.05)$ increase in cake cell uniformity, grain and texture being $27.4,18.5$ and 27.5 , respectively when compared to 26.4 which given by rice flour cake. Also, no significant $(\mathrm{p} \leq 0.05)$ difference was observed in gluten-free cake texture prepared with $30 \%$ of sorghum flour and $20 \%$ of germinated chickpea flour with rice flour cake. On the other 
Table 5. Mean scores of sensory characteristics of prepared gluten-free cakes.

\begin{tabular}{lcccccc}
\hline Treatments & $\begin{array}{c}\text { Cell } \\
\text { uniformity } \\
(30)\end{array}$ & $\begin{array}{c}\text { Grain } \\
(20)\end{array}$ & $\begin{array}{c}\text { Texture (30) } \\
\text { color (10) }\end{array}$ & $\begin{array}{c}\text { Crumb } \\
\text { Flavor (10) }\end{array}$ & $\begin{array}{c}\text { Overall } \\
\text { acceptability } \\
(100)\end{array}$ \\
\hline Wheat flour cake & $28.6 \pm 0.12^{\mathrm{a}}$ & $19.3 \pm 0.09^{\mathrm{a}}$ & $29.4 \pm 0.11^{\mathrm{a}}$ & $8.7 \pm 0.06^{\mathrm{c}}$ & $9.5 \pm 0.12^{\mathrm{a}}$ & $95.6 \pm 0.28^{\mathrm{a}}$ \\
Rice flour cake & $26.4 \pm 0.16^{\mathrm{c}}$ & $17.7 \pm 0.17^{\mathrm{cd}}$ & $26.6 \pm 0.32^{\mathrm{c}}$ & $9.1 \pm 0.10^{\mathrm{b}}$ & $8.5 \pm 0.11^{\mathrm{b}}$ & $88.4 \pm 0.22^{\mathrm{c}}$ \\
Cake with 20\% SF & $27.4 \pm 0.15^{\mathrm{b}}$ & $18.5 \pm 0.10^{\mathrm{b}}$ & $27.5 \pm 0.33^{\mathrm{b}}$ & $9.3 \pm 0.20^{\mathrm{ab}}$ & $8.4 \pm 0.10^{\mathrm{b}}$ & $90.7 \pm 0.34^{\mathrm{b}}$ \\
Cake with 30\% SF & $26.2 \pm 0.13^{\mathrm{c}}$ & $18.0 \pm 0.21^{\mathrm{bc}}$ & $26.6 \pm 0.12^{\mathrm{c}}$ & $9.2 \pm 0.05^{\mathrm{ab}}$ & $8.6 \pm 0.16^{\mathrm{b}}$ & $88.6 \pm 0.41^{\mathrm{c}}$ \\
Cake with 40\% SF & $23.5 \pm 0.15^{\mathrm{e}}$ & $17.4 \pm 0.15^{\mathrm{de}}$ & $22.7 \pm 0.12^{\mathrm{e}}$ & $9.5 \pm 0.09^{\mathrm{a}}$ & $8.0 \pm 0.21^{\mathrm{c}}$ & $81.2 \pm 0.33^{\mathrm{e}}$ \\
Cake with 20\% GCF & $25.4 \pm 0.14^{\mathrm{d}}$ & $17.0 \pm 0.21^{\mathrm{ef}}$ & $27.0 \pm 0.22^{\mathrm{bc}}$ & $8.6 \pm 0.11^{\mathrm{c}}$ & $9.3 \pm 0.10^{\mathrm{a}}$ & $87.5 \pm 0.50^{\mathrm{c}}$ \\
Cake with 30\% GCF & $24.9 \pm 0.21^{\mathrm{d}}$ & $16.7 \pm 0.25^{\mathrm{f}}$ & $25.7 \pm 0.24^{\mathrm{d}}$ & $7.6 \pm 0.16^{\mathrm{d}}$ & $8.5 \pm 0.15^{\mathrm{b}}$ & $83.6 \pm 0.62^{\mathrm{d}}$ \\
Cake with 40\% GCF & $21.5 \pm 0.33^{\mathrm{f}}$ & $13.7 \pm 0.24^{\mathrm{g}}$ & $22.4 \pm 0.15^{\mathrm{e}}$ & $6.4 \pm 0.15^{\mathrm{e}}$ & $7.4 \pm 0.13^{\mathrm{d}}$ & $71.5 \pm 0.76^{\mathrm{f}}$ \\
\hline
\end{tabular}

SF: Sorghum flour; GCF: Germinated chickpea flour; Data are the mean \pm SE, $n=10$, Mean values in the same column bearing the same superscript do not differ significantly $(\mathrm{p} \leq 0.05)$.

hand, adding $40 \%$ of germinated chickpea flour in gluten-free cake preparation resulted in significant $(\mathrm{p} \leq 0.05)$ decreased in all organoleptic parameters as compared to wheat, rice flours cake and investigated samples. These obtained results may be related with results of specific volume of prepared gluten-free cake which found in Table 3. Whereas, the cake samples prepared with 20 and $30 \%$ of sorghum flour and $20 \%$ of germinated chickpea flour which recorded high values in specific volumes were accepted by panelists in cake cell uniformity, grain and texture when compared with other replacement concentrations of sorghum flour and germinated chickpea flour. These results are in agreement with Hussein et al., [41] as they indicated that grain, texture, and flavor properties of gluten-free cake samples were not affected significantly when using sorghum, gelatinized corn, germinated rice, rice flours, and their mixture when compared with control wheat flour cake.

It was clearly noticed that using sorghum flour at substitution levels $20 \%, 30 \%$ and $40 \%$ in gluten-free cake preparation caused significant $(\mathrm{p} \leq 0.05)$ high in crumb color which recorded 9.3, 9.2 and 9.5, respectively as compared to wheat and rice flours cakes. These results may be attributed to the high lightness $\left(\mathrm{L}^{*}\right)$ color of sorghum flour used in this study (Table 4) and with increasing substitution levels from $20 \%$ to $40 \%$ of sorghum flour, the crumb color of prepared gluten-free cake was improved as indicated by the panelists. Man et al., [43] stated that the bread slices color became visually darker as the chickpea flour level increased. Also, a darker color of the crumbs was reported by Fărcaş et al., [44] and linked directly to increased fiber content and to the high content in carotenoids.

As can be expected, wheat flour cake had the highest score of flavor (9.5) followed by cake prepared with $20 \%$ of germinated chickpea flour which given 9.3 and without significant difference between them when compared with other gluten-free cake samples. In addition, no significant $(\mathrm{p} \leq 0.05)$ difference was found in cake flavor between rice flour cake being 8.5 with $20,30 \%$ of sorghum 
flour and 30\% of germinated chickpea flour which recorded 8.4, 8.6 and 8.5, respectively. The same trend was found for overall acceptability which improved when adding $20 \%, 30 \%$ of sorghum flour and $20 \%$ of germinated chickpea flour in gluten-free cake which being $90.7,88.6$ and 87.5 , respectively as compared to rice flour cake (88.4). Moreover, substituting of rice flour at $40 \%$ with sorghum or germinated chickpea flour in cake preparation resulted in significant ( $\mathrm{p} \leq$ $0.05)$ decrease and were rejected by panelists in overall acceptability which given 81.2 and 71.5 , respectively. Preichardt et al., [45] reported that $0.3 \%$ and $0.4 \%$ of xanthan gum produced desirable sensory gluten-free cakes with high acceptance by the consumers. The cakes resembled physically and sensorial to the control cake made with only wheat flour. From the previous results, it could be concluded that gluten-free cake quality could be enhanced when using sorghum flour at $20,30 \%$ and germinated chickpea flour at $20 \%$ as a substitution levels of rice flour in gluten-free cake processing.

\subsection{Staling Rate of Gluten-Free Cake Samples}

Results in Table 6 showed staling rate (freshness) of gluten-free cake samples prepared with substituting of rice flour at $20 \%, 30 \%$ and $40 \%$ by sorghum or germinated chickpea flours during six days of storage at room temperature $\left(24^{\circ} \mathrm{C} \pm 2^{\circ} \mathrm{C}\right)$. Data indicated that rice flour cake was more freshness than wheat flour cake and other treatments during all storage duration. Similar results were obtained by Hussein et al. [41], they found that rice cake sample producing from rice flour had the highest values of freshness. Also, there was gradually increase in staling (low AWRC \%) of gluten-free cake with all partial replacement levels and with storage periods up to 6 days. At zero time, no significant $(\mathrm{p} \leq 0.05)$ difference was observed in staling between cake samples containing $20 \%$ of sorghum or germinated chickpea flours which recorded $357.2 \%$ and $352.3 \%$, respectively. After 2 and 4 days of storage, it could be seen that with increasing of

Table 6. Staling rate (AWRC \%) of gluten-free cakes during storage periods at room temperature $\left(24^{\circ} \mathrm{C} \pm 2^{\circ} \mathrm{C}\right)$.

\begin{tabular}{lcccc}
\hline \multirow{2}{*}{ Treatments } & \multicolumn{4}{c}{ Storage periods (days) } \\
\cline { 2 - 5 } & 0 & 2 & 4 & 6 \\
\hline Wheat flour cake & $365.8 \pm 1.07^{\mathrm{Ab}}$ & $352.6 \pm 1.33^{\mathrm{Bb}}$ & $327.2 \pm 1.58^{\mathrm{Cb}}$ & $304.8 \pm 2.09^{\mathrm{Da}}$ \\
Rice flour cake & $381.4 \pm 3.49^{\mathrm{Aa}}$ & $367.8 \pm 1.76^{\mathrm{Ba}}$ & $335.7 \pm 1.06^{\mathrm{Ca}}$ & $306.2 \pm 2.95^{\mathrm{Da}}$ \\
Cake with 20\% SF & $357.2 \pm 2.03^{\mathrm{Ac}}$ & $343.7 \pm 0.98^{\mathrm{Bc}}$ & $328.8 \pm 3.58^{\mathrm{Cb}}$ & $294.5 \pm 2.31^{\mathrm{Db}}$ \\
Cake with 30\% SF & $336.8 \pm 2.33^{\mathrm{Ad}}$ & $321.8 \pm 1.46^{\mathrm{Be}}$ & $304.9 \pm 2.60^{\mathrm{Cd}}$ & $283.1 \pm 1.73^{\mathrm{Dc}}$ \\
Cake with 40\% SF & $327.5 \pm 1.74^{\mathrm{Ae}}$ & $314.3 \pm 1.81^{\mathrm{Bf}}$ & $275.6 \pm 2.89^{\mathrm{Cf}}$ & $261.5 \pm 0.86^{\mathrm{De}}$ \\
Cake with 20\% GCF & $352.3 \pm 1.65^{\mathrm{Ac}}$ & $337.4 \pm 2.61^{\mathrm{Bd}}$ & $316.5 \pm 1.90^{\mathrm{Cc}}$ & $289.4 \pm 0.92^{\mathrm{Db}}$ \\
Cake with 30\% GCF & $339.2 \pm 1.44^{\mathrm{Ad}}$ & $319.7 \pm 2.65^{\mathrm{Bef}}$ & $297.3 \pm 1.15^{\mathrm{Ce}}$ & $272.6 \pm 0.94^{\mathrm{Dd}}$ \\
Cake with 40\% GCF & $312.6 \pm 2.02^{\mathrm{Af}}$ & $294.3 \pm 1.64^{\mathrm{Bg}}$ & $268.4 \pm 3.58^{\mathrm{Cg}}$ & $248.3 \pm 1.73^{\mathrm{Df}}$ \\
\hline
\end{tabular}

SF: Sorghum flour; GCF: Germinated chickpea flour; Data are the mean \pm SE, $n=3$, Values followed by the same capital letters in the same row; and values followed by the same small letters in the same column are not significantly different $(\mathrm{p} \leq 0.05)$. 
substituting levels from $20 \%$ to $40 \%$ with sorghum or germinated chickpea flours, the freshness of resulted cake samples was significantly $(\mathrm{p} \leq 0.05)$ decreased as compared with wheat or rice flour cakes. Moreover, gluten-free cake samples containing $40 \%$ of sorghum or germinated chickpea flours had the highest firmness values beginning of storage time and until 6 days of storage. The same trend was observed after 6 days whereas, rice cake had significant $(\mathrm{p} \leq$ 0.05) high in freshness being $306.2 \%$ followed by gluten-free cake samples with $20 \%$ of sorghum or germinated chickpea flours which given $294.5 \%$ and $289.4 \%$, respectively. Generally, it could be concluded that the results of staling rate of gluten-free cakes were compatible with those of sensory evaluation in Table 5 where the best substituting levels in gluten-free cake were $20,30 \%$ of sorghum flour and 20\% of germinated chickpea flour. Preichardt et al., [45] reported that the gluten-free cakes firmness increased with the length of storage, but the xanthan postponed the hardening of the cakes.

\section{Conclusion}

It could be concluded that gluten-free cakes enriched in crude protein, fibers and minerals can be prepared by substituting of rice flour with sorghum and germinated chickpea flours. With increasing the substituting levels of rice flour from $20 \%$ to $40 \%$ with sorghum or germinated chickpea flours, maximum viscosity and setback of cake batters were decreased compared with rice flour batter. No significant difference was found in specific volume between wheat cake, rice cake and cake with $20 \%$ germinated chickpea flour. Previous results suggested that using sorghum flour at $20,30 \%$ and germinated chickpea flour at $20 \%$ as substitution levels of rice flour produced the healthy gluten-free cakes with acceptable freshness and sensory properties for coeliac patients. Future studies will be needed for evaluating the effect of other grains and legumes on quality and consumer acceptable of enriched gluten-free cakes.

\section{References}

[1] Lerner, A. (2010) New Therapeutic Strategies for Celiac Disease. Autoimmunity Reviews, 9, 144-147. https://doi.org/10.1016/j.autrev.2009.05.002

[2] Hill, I.D., Dirks, M.H., Liptak, G.S., Colletti, R.B., Fasano, A., Guandalini, S., et al. (2005) Guideline for the Diagnosis and Treatment of Celiac Disease in Children: Recommendations of the North American Society for Pediatric Gastroenterology, Hepatology and Nutrition. Journal of Pediatric Gastroenterology Nutrition, 40, 119.

[3] Matos, M.E. and Rosell, C.M. (2011) Chemical Composition and Starch Digestibility of Different Gluten-Free Breads. Plant Foods for Human Nutrition, 66, 224-230. https://doi.org/10.1007/s11130-011-0244-2

[4] Torbica, A., Hadnadev, M. and Dapcevic, T. (2010) Rheological, Textural and Sensory Properties of Gluten-Free Bread Formulations Based on Rice and Buckwheat Flour. Food Hydrocolloids, 24, 626-632.

[5] Helm, R.M. and Burks, A.W. (1996) Hypoallergenicity of Rice Protein. Cereal Foods World, 41, 839-843.

[6] Ciacci, C., Maiuri, L., Caporaso, N., Bucci, C., Del Giudice, L., Rita Massardo, D., 
Pontieri, P., Di Fonzo, N., Bean, S.R., Ioerger, B. and Londei, M. (2007) Celiac Disease: In Vitro and in Vivo Safety and Palatability of Wheat-Free Sorghum Food Products. Clinical Nutrition, 26, 799-805.

[7] Aharon, S., Badani, H., Galili, L., Hovav, R., Kapulnik, Y., Shomer, I. and Galili, S. (2012) Effects of Baking, Roasting and Frying on Total Polyphenols and Antioxidant Activity in Colored Chickpea Seeds. Food and Nutrition Sciences, 3, 369-376. https://doi.org/10.4236/fns.2012.33053

[8] FAOSTAT (2012). http://faostat.fao.org/default.aspx

[9] Muzquiz, M. and Wood, J.A. (2007) Antinutritional Factors. In: Yadav, S.S., Redden, B., Chen, W. and Sharma, B., Eds., Chickpea Breeding and Management, CAB International, Wallingford, 143-166. https://doi.org/10.1079/9781845932138.006

[10] Wood, J.A. and Grusak, M.A. (2007) Nutritional Value of Chickpea. In: Yadav, S.S., Redden, B., Chen, W. and Sharma, B., Eds., Chickpea Breeding and Management, CAB International, Wallingford, 101-142. https://doi.org/10.1079/9781845932138.005

[11] Cevallos-Casals, B.A. and Cisneros-Zevallos, L. (2010) Impact of Germination on Phenolic Content and Antioxidant Activity of 13 Edible Seed Species. Food Chemistry, 119, 1485-1490.

[12] Herranz, B., Canet, W., Jiménez, M., Fuentes, R. and Alvarez, M.D. (2016) Characterization of Chickpea Flour-Based Gluten-Free Batters and Muffins with Added Biopolymers: Rheological, Physical and Sensory Properties. International Journal of Food Science \& Technology, 51, 1087-1098. https://doi.org/10.1111/ijfs.13092

[13] Moore, M.M., Heinbockel, M., Dockery, P., Ulmer, H.M. and Arendt, E.K. (2006) Network Formation in Gluten-Free Bread with Application of Transglutaminase. Cereal Chemistry, 83, 28-36. https://doi.org/10.1094/CC-83-0028

[14] Lazaridou, A.D., Duta, M., Papageorgiou, N.B. and Biliaderis, C.G. (2007) Effects of Hydrocolloids on Dough Rheology and Bread Quality Parameters in Gluten-Free Formulations. Journal of Food Engineering, 79, 1033-1047.

[15] Abdelghafor, R.F., Mustafa, A.I., Ibrahim, A.M.H., Chen, Y.R. and Krishnan, P.G. (2013) Effects of Sorghum Flour Addition on Chemical and Rheological Properties of Hard White Winter Wheat. Advance Journal of Food Science and Technology, 5, 1407-1412.

[16] Fernandez-Orozco, R., Frias, J., Zielinski, H., Munoz, R., Piskula, M., Kozlowska, H. and Vidal-Valverde, C. (2009) Evaluation of Bioprocesses to Improve the Antioxidant Properties of Chickpeas. LWT-Food Science and Technology, 42, 885-892.

[17] AOAC (2000) Official Methods of Analysis. 17th Edition, Association of Official Analytical Chemists International. Gaithersburg, MD.

[18] Hagerman, A.E. (1987) Radial Diffusion Method for Determining Tannins in Plant Extracts. Journal of Chemistry Ecology, 13, 437-449. https://doi.org/10.1007/BF01880091

[19] Hamerstrand, G.E., Black, L.T. and Glover, J.D. (1981) Trypsin Inhibitors in Soy Products Modification of the Standard Analytical Procedure. Cereal Chemistry, 58, 42-45.

[20] AACC (2000) American Association of Cereal Chemists. Approved Methods of the A.A.C.C. Published by the American Association of Cereal Chemists, 10th Edition, St. Paul, MN.

[21] Levent, H. and Bilgiçli, N. (2011) Effect of Gluten-Free Flours on Physical Properties of Cakes. Journal of Food Science and Engineering, 1, 354-360.

[22] Jyotsna, R., Prabhasankar, P., Indrani, D. and Rao, G.V. (2004) Improvement of 
Rheological and Baking Properties of Cake Batters with Emulsifier Gels. Journal of Food Science, 69, 16-19. https://doi.org/10.1111/j.1365-2621.2004.tb17880.x

[23] Bennion, E.B. and Bamford, G.S.T. (1997) The Technology of Cake Making. 6th Edition, Blacking Academic and Professional, Chapman \& Hall, London, 112-120, 277, 285-288. https://doi.org/10.1007/978-1-4757-6690-5

[24] Francis, F.J. (1983) Colorimetry of Foods. In: Peleg, M. and Bagly, E.B., Eds., Physical Properties of Foods, The AVI Publishing Company Inc., Westport, CT, 105-123.

[25] Snedecor, G.W. and Cochran, W.G. (1980) Statistical Methods. 7th Edition, Iowa State University Press, Ames, IA.

[26] SAS, (1996) SAS/Stat Users Guide: Statistics, System for Windows. Version 4.10 (Release 6.12 TS level 0020), SAS Inst., Inc., Cary, NC.

[27] Yousif, M.R.G. and Faid, S.M. (2014) Supplementation of Gluten-Free Bread with Some Germinated Legumes Flour. Journal of American Science, 10, 84-93.

[28] Ranjbar, S., Movahhed, S., Nematti, N. and Sokotifar, R. (2012) Evaluation of the Effect of Carboxy Methyl Cellulose on Sensory Properties of Gluten-Free Cake. Research Journal of Applied Sciences, Engineering and Technology, 4, 3819-3821.

[29] Kohajdová, Z., Karovičová, J. and Schmidt, S. (2011) Lupine Composition and Possible Use in Bakery-A Review. Journal of Food Science, 29, 203-211.

[30] Maghaydah, S., Abdul-hussain, S., Ajo, R., Tawalbeh, Y. and Elsahoryi, N. (2013) Effect of Lupine Flour on Baking Characteristics of Gluten-Free Cookies. Advance Journal of Food Science and Technology, 5, 600-605.

[31] Ghavidel, R.A. and Prakash, J. (2007) The Impact of Germination and Dehulling on Nutrients, Antinutrients, in Vitro Iron and Calcium Bioavailability and in Vitro Starch and Protein Digestibility of Some Legume Seeds. LWT-Food Science and Technology, 40, 1292-1299.

[32] Babajide, J.M. and Olowe, S. (2013) Chemical, Functional and Sensory Properties of Water Yam-Cassava Flour and Its Paste. International Food Research Journal, 20, 903-909.

[33] Jan, R., Seema, E., Saxena, D.C. and Singh, S. (2013) Pasting and Thermal Properties of Starch Extracted from Chenopodium album Grain. International Journal of Agriculture and Food Science Technology, 4, 981-988.

[34] Shevkani, K., Kaur, A., Kumar, S. and Singh, N. (2015) Cowpea Protein Isolates: Functional Properties and Application in Gluten-Free Rice Muffins. LWT-Food Science and Technology, 63, 927-933.

[35] Lee, M.H., Hettiarachchy, N.S., McNew, R.W. and Gnanasambandam, R. (1995) Physicochemical Properties of Calcium-Fortified Rice. Cereal Chemistry, 72, 352355.

[36] Shevkani, K., Kaur, A., Singh, G., Singh, B. and Singh, N. (2014) Composition, Rheological and Extrusion Behaviour of Fractions Produced by Three Successive Reduction Dry Milling of Corn. Food and Bioprocess Technology, 7, 1414-1423. https://doi.org/10.1007/s11947-013-1194-5

[37] Ouazib, M., Dura, A., Zaidi, F. and Rosell, C.M. (2016) Effect of Partial Substitution of Wheat Flour by Processed (Germinated, Toasted, Cooked) Chickpea on Bread Quality. International Journal of Agricultural Science and Technology, 4, 8-18. https://doi.org/10.12783/ijast.2016.0401.02

[38] Kim, C.S. and Walker, C.E. (1992) Interactions between Starches, Sugars and Emulsifiers in High-Ratio Cake Model Systems. Cereal Chemistry, 69, 206-212.

[39] Khalil, A.H. (1998) The Influence of Carbohydrate-Based Fat Replacers with and without Emulsifiers on the Quality Characteristics of Low Fat Cake. Plant Foods for 
Human Nutrition, 52, 299-313. https://doi.org/10.1023/A:1008096031498

[40] Gomez, M., Oliete, B., Rosell, C.M., Pando, V. and Fernandez, E. (2008) Studies on Cake Quality Made of Wheat-Chickpea Flour Blends. LWT-Food Science and Technology, 41, 1701-1709.

[41] Hussein, A.M.S., Hegazy, N.A. and Ibrahim ,T.A.A. (2012) Production and Evaluation of Gluten-Free Cakes. Australian Journal of Basic and Applied Sciences, 6, 482-491.

[42] Xu, L. and Diosady, L.L. (2000) Interactions between Canola Proteins and Phenolic Compounds in Aqueous Media. Food Research International, 33, 725-731.

[43] Man, S., Pnucean, A., Muste, S. and Pop, A. (2015) Effect of the Chickpea (Cicer arietinum L.) Flour Addition on Physicochemical Properties of Wheat Bread. Bulletin UASVM Food Science and Technology, 72, 41-49. https://doi.org/10.15835/buasvmcn-fst:11023

[44] Fărcaş, A.C, Socaci, S.A., Tofană, M., Mureşan, C., Mudura, E., Salanță, L. and Scrob, S. (2014) Nutritional Properties and Volatile Profile of Brewer's Spent Grain Supplemented Bread. Romanian Biotechnological Letters, 19, 9705-9714.

[45] Preichardt, L.D., Vendruscolo, C.T., Gularte, M.A. and Moreira, A.S. (2011) The Role of Xanthan Gum in the Quality of Gluten-Free Cakes: Improved Bakery Products for Coeliac Patients. International Journal of Food Science and Technology, 46, 2591-2597. https://doi.org/10.1111/j.1365-2621.2011.02788.x

\section{Scientific Research Publishing}

Submit or recommend next manuscript to SCIRP and we will provide best service for you:

Accepting pre-submission inquiries through Email, Facebook, LinkedIn, Twitter, etc. A wide selection of journals (inclusive of 9 subjects, more than 200 journals)

Providing 24-hour high-quality service

User-friendly online submission system

Fair and swift peer-review system

Efficient typesetting and proofreading procedure

Display of the result of downloads and visits, as well as the number of cited articles

Maximum dissemination of your research work

Submit your manuscript at: http://papersubmission.scirp.org/

Or contact fns@scirp.org 